\title{
2005 Plenary Session Will Be Enlightening and Entertaining
}

\author{
By Ellen Humphries
}

\section{$\mathrm{A}$}

$\mathrm{n}$ entertainer, an environmentalist, an economic developer, and an elected officialthese are among the speakers invited by the 2005 Planning Committee to highlight the plenary session at the 58th annual meeting of the Society for Range Management (SRM), February 5-11, Fort Worth, Texas.

\section{What were they thinking?!}

Conference cochairs Dan Caudle and George Peacock say the plenary session sets the tone for the entire SRM conference. "Our theme is 'Rangeland Trails under the Lone Star," Caudle says. "Our thoughts from the very beginning were that trails come from all directions. They converge, then diverge and create a network that extends in all directions. These speakers are people who all have a common interest in rangelands, but their interests come from different sources and lead in different directions."

Peacock adds, "Historically the main trails were ranching. Then, we moved off into the new issues of the urban-rural interface, of rural economic development for our communities. We see different uses of the rangelands today compared to traditional uses."

"I don't know if this is a real change in thinking within rangeland managers and SRM. Most of the range ecologists were multidiscipline anyway - this idea of multiuse is just gaining greater awareness," Peacock says.

The rest of the conference program, preconference workshops, technical sessions, technical tours, and symposia will mesh with this theme.

"From Fossil Rim to the Botanical Research Institute of Texas to traditional ranching to cultural and heritage tours, there's something for everybody," Caudle says.

\section{Entrepreneur}

Among those invited is Ed Bass, area rancher, businessperson, and community philanthropist. Bass has graciously offered one of his ranches as a tour site during the 2005 technical tours. Bass has been invited to speak on the challenges of ranching in North Texas.

\section{Western Author}

Elmer Kelton is a noted Texas author who has written and published more than 40 western novels over more than 50 years. Four of his books have won the Western Heritage Award from the National Cowboy Hall of Fame, and 6 have won the Spur Award from the Western Writers of America.

His best-known and most critically acclaimed works include The Time It Never Rained, The Good Ole Boys, The Day the Cowboys Quit, and The Wolf and the Buffalo.

Kelton was born at the Horse Camp on the Five Wells Ranch in Andrews County and grew up on the McElroy Ranch near Crane. He served in the US Army from 1944 through 1946, including combat infantry service in Europe.

Kelton received his BA degree in journalism from the University of Texas in 1948. He was the farm and ranch writer-editor for the San Angelo Standard-Times newspaper for 15 years, editor of the Sheep and Goat Raiser magazine for 5 years, and associate editor of the Livestock Weekly for 22 years until his retirement in 1990. Since that time, Elmer has devoted full time to being a novelist and speaker.

His ranch background and his agricultural/livestock journalism experience have provided him with a unique perspective and ability to capture the characteristics of the western landscape and the people who live there. 


\section{Elected Official}

Texas Commissioner of Agriculture Susan Combs will speak on the importance of Texas' rangelands. Combs is uniquely qualified for this subject, having a ranch of her own in Brewster County in West Texas.

Combs, a 4th-generation rancher, was sworn into office in 1999 as the state's 10th commissioner of agriculture and the 1st woman to hold this position in the state's history. She was overwhelmingly reelected to the position in 2002.

For her outstanding work for Texas farmers and ranchers, Combs was named Progressive Farmer's Leader of the Year in Texas Agriculture for 2002.

She has twice been invited to lecture at the Harvard Business School on the US-Mexico water situation. In 2003, she was named cochair of NASDA's Tri National Accord, US-Mexico Working Group.

\section{Entertainer}

Michael Martin Murphey, our kickoff gala entertainer, will be part of the plenary session, offering his thoughts on how rangelands have impacted American music.

Murphey, known as a "singing cowboy poet," is the best-selling singer/songwriter of American cowboy music and a respected singer/songwriter in the pop and country-and-western field.

Artistically, Murphey is more landscape driven than other musicians. His heroes are painters like Charlie Russell, Frederick Remington, Buck Dunton, Ernest Blumenshien, Georgia O'Keefe, and Maynard Dixon. Murphey's close friends have always been contemporary artists like William C. Matthews, Amado Pena, Gary Roller, and Jerry Riness. In philosophy, his heroes are Christian thinkers like Albert Schweitzer, Thomas Merton, and C. S. Lewis.

Murphey advocates the study, preservation, and respect of American culture-especially the elements the world loves about Americans: individualism, outdoor adventure, cowboys, Indians, and the songwriting traditions of popular and "roots" American music. He is a witness for Christianity as a faith and philosophy of life, with respect for other world religions.

\section{Economic Developer}

Remelle Farrar, director of the Texas Prairie Rivers Association, will discuss how the Texas Prairie Rivers project is bringing economic opportunities to rural communities in the Texas Panhandle.

"Remelle has talked at several meetings I've been at in the Texas Panhandle and Oklahoma," Caudle says. "Her organization tries to help the economy of the rural communities, which are dependent upon ranching and agriculture for their existence."

Caudle continues, "She gets those traditional, conservative ranchers up there to loosen up a little bit." Many times, Farrar has faced opposition but has managed to convince area ranchers to try various economic development options, such as ecotourism, with measurable success.

"When she first started working with one rancher, he was totally against what she was doing, and now they have busloads of bird-watchers from Houston visit the ranch every year for prairie chicken booming season."

Texas Prairie Rivers has a series of conservation programs that integrate habitat integrity with outreach and education. Texas Prairie Rivers supports a critical study being carried out by Ben Toole of Texas A\&M University on the populations of lesser prairie chickens, an icon species and a barometer of the overall health of Prairie Rivers grasslands.

Texas Prairie Rivers administers and oversees a grant from the National Fish and Wildlife Foundation (NFWF) aimed at creating a regional approach toward grassland conservation. This project includes extensive outreach with school-aged students, partnering with major corporations to create buy-in for conservation projects, and working closely with landowners to provide resources and training that can be used to stimulate outdoor-based recreations such as hiking, birding, and camping.

Members of Texas Prairie Rivers lead in conservation by promoting the message of economic diversification of rangelands. One of the most important components in the NFWF conservation project is the inclusion of grassland habitats far outside Panhandle political borders but well within its physiographic region. Ranchers as far away as Wyoming have joined with the twin sisters of conservation 
and economic diversification.

Texas Prairie Rivers accomplishes most of its buyin and stakeholder support because the organization itself was founded and directed by ranchers. Texas Prairie Rivers is apolitical, inclusive, and cooperative in nature with a keen sensitivity to private property issues, landowner liability, and the implications of the Endangered Species Act as it relates to private lands.

\section{Environmentalist}

Julie Shackelford, with The Conservation Fund and American Farmland Trust, will explain the trend of land fragmentation taking place on Texas' rangelands and how this is leading to a more active urban-rural interface.

The Texas of legend is a land of vast, wide-open spaces. The reality, however, is that over the past 30 years the average size of land ownership - the average acreage of landholdings - in Texas has been shrinking dramatically.

A March 2003 report from Texas Cooperative Extension of the Texas A\&M University System and American Farmland Trust, titled "Texas Rural Lands: Trends and Conservation Implications for the 21 st Century," assesses the extent of land fragmentation in Texas and identifies predictors that warn of areas around the state most at risk for fragmentation.

"Going, Going, Gone: The Impact of Land Fragmentation on Texas Agriculture and Wildlife" summarizes some of the findings of that report by discussing the effect of land fragmentation on our citizens, wildlife, farming, ranching, and water supplies. This study outlines gains made by American Farmland Trust with an eye toward conserving family lands and the Texas landscapes of our memory.

To accommodate new landowners, the vast farms and famous Texas ranches are being rapidly splintered into smaller and smaller pieces. Each year since 1970 , about 1,000 new farms and ranches have been established in Texas. At the same time, the total area devoted to agricultural uses declined by almost 3 million acres. That's 33,000 more farms and ranches on 3 million fewer acres. This process is part of a trend known as land fragmentation.
Those new "ranchettes" are typically too small for traditional farming, ranching, or forestry. But that's fine with most new landowners who have limited interest in working the land. Instead, they want a place where they can escape the crowds and noise of urban life. They want to do a little hunting, explore the countryside, own a few cattle, and reconnect with the spirit of the Old West. One recent survey of new landowners by the Texas A\&M University's Real Estate Center found that $80 \%$ of buyers said that finding land for nonagricultural uses, like hunting, fishing, and other recreation, was a "very important" motive for their purchase.

Sadly, this rush to embrace the land may be ruining it. Thousands of new ranchettes are gobbling up open space and degrading wildlife habitat while at the same time depleting and polluting scarce water resources.

While this loss due to "urban sprawl" was confined primarily to the fringes of our major metropolitan areas, the fragmentation of agricultural lands into smaller ownerships has occurred in areas that had not previously been affected by urban sprawl. Fragmentation is starting to eat away at large ownerships even in areas such as the Trans Pecos and South Texas, which seem the very definition of "wide-open spaces." This fragmentation is likely to continue in some of the most rural areas of the state where natural amenities such as recreation potential and scenic beauty are in high demand.

"Texas Rural Lands: Trends and Conservation Implications for the 21 st Century" examined the issue of land fragmentation and its impact on land uses across the state and found that this phenomenon is rapidly transforming Texas. The changes often go unnoticed by the average Texan, but those close to the land see the consequences. Things are changing.

\section{Engage Yourself in the Session}

These and more diverse topics will be discussed at the 2005 meeting. Plan to be in Fort Worth February 5-11 to engage in these opportunities to broaden your thinking about the multiple uses of rangeland and how this resource affects our culture. 